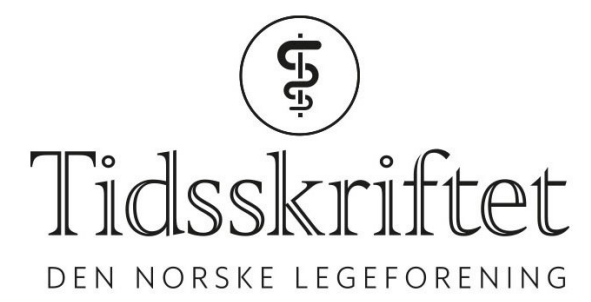

\title{
Protrahert bakteriell bronkitt?
}

KOMMENTAR

\section{ASLAK HOVDA LIEN}

E-post:ahl@lenvik.kommune.no

Aslak Hovda Lien er kommuneoverlege i Senjalegen og medisinsk faglig ansvarlig på Finnsnes IK Legevakt.

Ingen oppgitte interessekonflikter.

Artikkelen Protrahert bakteriell bronkitt hos barn av K. Øymar og medforfattere har utløst debatt. Les hele diskusjonen på våre nettsider.

Følgende kommentar er basert kun på egen reaksjon og refleksjon rundt artikkelen (1). Perspektivet er fra kommunehelsetjeneste og legevakt i en relativt rural del av landet.

Jeg stusser på hva både budskap og intensjon i artikkelen er ment å være. Som artikkelen selv sier skyldes infeksjonsutløst hoste i hovedsak virale infeksjoner og gir hoste som varer i gjennomsnitt tre uker. Kronisk hoste defineres ofte som hoste som varer mer enn åtte uker.

Artikkelen er problematisk fordi jeg oppfatter den som en argumentasjon for at protrahert bakteriell bronkitt er:

1. En vanlig og underdiagnostisert bakteriell luftveisinfeksjon hos barn, dvs. et signal på at mange flere barn burde vært behandlet med antibiotika.

2. En diagnose som settes på klinisk mistanke på bakgrunn av fuktig hoste som har vart mer enn fire uker, og som ikke kan identifiseres vha. infeksjonsparameter, radiologiske undersøkelser eller dyrkning etter bronkoskopi.

3. En tilstand som skal behandles med bredspektret antibiotika i 2-4 uker. Valg av antibiotika er ikke i tråd med nasjonale retningslinjer for antibiotika, nærmest diametralt motsatte: antibiotika med utvidet eller bredt spekter som amoxicillin, makrolider og cafalosporiner på en antatt infeksjon uten funn på blodprøver, røntgen eller bronkoskopi? Og der manglende antibiotikarespons etter to uker brukes som argument for å forlenge behandlingen ytterligere to uker?

4. En tilstand adskilt fra astma ved at hosten er fuktig, mot at astmahoste er tørr. Dette passer dårlig med de tre patofysiologiske komponentene bak astma, der en av komponentene er økt slimproduksjon?

Jeg oppfatter at den største utfordringen vi har knyttet til hoste ved luftveisinfeksjoner hos barn, er en for liberal forskrivning av antibiotika på et for dårlig grunnlag. Hoste, både fuktig og tørr, er svært vanlig hos barn. Derfor syns jeg en artikkel som oppfattes å anbefale til mer liberal bruk av bredspektrede og langvarige antibiotikakurer ved hoste hos barn, legger opp til både overbehandling og feilaktig antibiotikabruk. At pediatere anbefales å stå for forskrivningen, syns jeg ikke endrer noe på dette poenget. 
Videre blir det ikke bedre av at de diagnostiske kriteriene for tilstanden ikke stiller krav til positive infeksjonsprøver, patologiske røntgenfunn eller oppvekst i mikrobielle prøver fra luftveiene. Fuktig hoste hos barn med varighet over fire uker, uten andre funn, syns jeg virker som et syltynt grunnlag for antibiotikaoppstart. At tilstanden beskrives som særlig vanlig hos barn som starter i barnehage, gjør det ekstra viktig å vite hvor vanlig dette er i Norge, all den tid svært mange barn har relativt mye hoste og luftveisinfeksjoner av godartet karakter første halvår i barnehage. At det vanligste agens for protahert bakteriell bronkitt, Haemophilus influenzae, inngår i det norske vaksinasjonsprogrammet, bør vel sannsynligvis tas med i betraktningen for hvor overførbare utenlandske data eventuelt er til Norge?

Langvarig hoste er et vanlig problem hos barn. Jeg er ikke uenig i at mange barn får bronkolytika mot sin hoste på tynt grunnlag. Men jeg ser ikke at det blir bedre av å erstatte Ventoline med Abboticin. Snarere tvert imot.

\section{LITTERATUR:}

1. Øymar K, Mikaelsen IB, Crowley S. Protrahert bakteriell bronkitt hos barn. Tidsskr Nor Legeforen 2017; 137: 1043 - 6. [CrossRef]

Publisert: 8. januar 2018. Tidsskr Nor Legeforen. DOI: 10.4045/tidsskr.17.1088

(C) Tidsskrift for Den norske legeforening 2020. Lastet ned fra tidsskriftet.no 